\title{
PENGARUH MODEL PEMBELAJARAN TPS BERBANTUAN MEDIA VISUAL TERHADAP HASIL BELAJAR IPA
}

\author{
Ni Komang Tri Julia Agustin ${ }^{1}$, I Gede Margunayasa ${ }^{2}$, Ni Nyoman Kusmariyatni ${ }^{3}$ \\ 1,2,3 Jurusan Pendidikan Guru Sekolah Dasar, FIP \\ Universitas Pendidikan Ganesha \\ Singaraja, Indonesia \\ email : julia.agustin37@gmail.com, igede.margunayasa@undiksha.ac.id ${ }^{2}$, \\ nyoman.kusmariyanti@undiksha.ac.id ${ }^{3}$
}

\begin{abstract}
Abstrak
Penelitian ini bertujuan untuk mengetahui perbedaan hasil belajar IPA antara kelompok siswa yang mengikuti pembelajaran dengan model Think Pair Share (TPS) berbantuan media visual dan kelompok siswa yang mengikuti pembelajaran dengan pembelajaran konvensional pada siswa kelas III semester II di SD Gugus Sriwijaya Kecamatan Pekutatan. Rancangan penelitian yang digunakan adalah Non equivalent Posttest-Only Control Group Design. Populasi penelitian adalah kelas III semester II di SD Gugus Sriwijaya Kecamatan Pekutatan tahun pelajaran 2017/2018 yang berjumlah 122 siswa. Sampel diambil dengan teknik random sampling. Sebanyak 29 siswa kelas III SD Negeri 1 Asahduren dan 27 siswa dari kelas III SD Negeri 2 Asahduren dipilih sebagai sampel. Data skor hasil belajar IPA dikumpulkan dengan instrumen tes pilihan ganda. Teknik analisis yang digunakan adalah uji-t independent. Hasil penelitian menunjukkan bahwa terdapat perbedaan hasil belajar IPA antara kelompok siswa yang mengikuti pembelajaran Think Pair Share (TPS) dan kelompok siswa yang mengikuti mpembelajaran konvensional, dengan nilai thitung sebesar 8,473 dan t tabel sebesar 2,021. Artinya, thitung lebih besar dari ttabel. Berdasarkan hasil penelitian tersebut, dapat disimpulkan bahwa model pembelajaran Think Pair Share (TPS) berpengaruh positif terhadap hasil belajar IPA pada siswa kelas III semester II di SD Gugus Sriwijaya Kecamatan Pekutatan tahun pelajaran 2017/2018.
\end{abstract}

Kata kunci: hasil belajar, TPS, Media Visual

\begin{abstract}
This study aimed to find out the difference of students' science achievement between groups of students who thought by using Think Pair Share (TPS) model collaborated with visual media and group of students who thought with conventional learning model in third grade students of second semester at SD Gugus Sriwijaya Pekutatan District. The research design used on this study was Non-equivalent with Post-test only Control Group Design. The population of this research was third grade students of second semester at SD Gugus Sriwijaya Pekutatan in academic year 2017/2018, totally there were 122 students. Samples were taken by using random sampling technique. As the samples totally there were 29 students from SD Negeri 1 Asahduren and 27 students from SD Negeri 2 Asahduren. The score on students' science achievement were collected by using multiple choice test instruments. The analysis technique used was independent t-test. The results showed that there were differences of science learning outcomes between the students who thought by using Think Pair Share (TPS) and the students who thought with conventional model, with the tcount of 8,473 and $t$ table 2,021. It means that, $t$ count is higher than ttable. Based on the results of this study, it can be concluded that the Think Pair Share (TPS) learning model has a positive effect on the third grade students' science achievement of second semester at SD Gugus Sriwijaya Pekutatan academic year 2017/2018.
\end{abstract}

Keywords: learning outcomes, TPS, Visual Media 


\section{Pendahuluan}

Pendidikan merupakan kegiatan yang kompleks, dan meliputi berbagai komponen yang berkaitan erat satu sama lain. Oleh sebab itu, apabila pendidikan ingin dilaksanakan secara terencana dan teratur, maka berbagai faktor yang terlibat dalam pendidikan harus dipahami terlebih dahulu. Berbagai komponen dalam sistem pendidikan, baik secara mikro maupun dalam kajian makro perlu dikenali secara mendalam sehingga komponen-komponen tersebut dapat difungsikan dan dikembangkan guna mengoptimalkan garapan pendidikan tersebut ke arah pencapaian tujuan pendidikan yang ditetapkan (Dinn Wahyudi dkk, 2006) (Sutrisno, 2016)

Pendidikan juga merupakan suatu proses yang diperlukan untuk mendapatkan keseimbangan dan kesempurnaan dalam perkembangan individu maupun masyarakat. Penekanan pendidikan dibanding dengan pengajaran terletak pada pembentukan kesadaran dan kepribadian individu atau masyarakat di samping transfer ilmu dan keahlian. Dengan proses semacam ini suatu bangsa atau negara dapat mewariskan nilai-nilai keagamaan, kebudayaan, pemikiran dan keahlian kepada generasi berikutnya, sehingga mereka betul-betul siap menyongsong masa depan kehidupan bangsa dan negara yang lebih cerah (Nurkholis, 2013).

Pasal 1 UU SISDIKNAS no. 20 tahun 2003 disebutkan bahwa Sistem Pendidikan Nasional adalah keseluruhan komponen pendidikan yang saling terkait secara terpadu untuk mencapai tujuan pendidikan nasional. Berangkat dari bunyi pasal ini dapat diketahui bahwa pendidikan adalah sistem yang merupakan suatu totalitas struktur yang terdiri dari komponen yang saling terkait dan secara bersama menuju kepada tercapainya tujuan (Soetarno, 2003: 2). Adapun komponen-komponen dalam pendidikan nasional antara lain adalah lingkungan, sarana-prasarana, sumberdaya, dan masyarakat. Komponen-komponen tersebut bekerja secara bersama-sama, saling terkait dan mendukung dalam mencapai tujuan pendidikan (Munirah, 2015).

Pendidikan adalah merupakan bagian integral dalam pembangunan. Proses Pendidikan tak dapat dipisahkan dari proses pembangunan itu sendiri. Pembangunan diarahkan dan bertujuan untuk mengembangkan sumber daya manusia yang berkualitas dan pembangunan sektor ekonomi yang satu dengan lainnya saling berkaitan dan berlangsung dengan berbarengan.

Dalam Undang - Undang Nomor 20 Tahun 2003 Bab I, Pasal 1 tentang Sistem Pendidikan Nasional disebutkan bahwa: "Pendidikan adalah usaha sadar dan terencana untuk mewujudkan suasana belajar dan proses pembelajaran agar peserta didik secara aktif mengembangkan potensi dirinya untuk memiliki kekuatan spiritual keagamaan, pengendalian diri, kepribadian, kecerdasan, akhlak mulia, serta keterampilan yang diperlukan dirinya, masyarakat, bangsa dan negara".

Meningkatkan kualitas pendidikan sejalan dengan pembangunan nasional sehingga mampu menghasilkan manusia yang berkualitas dan bersaing di era globalisasi. Salah satu komponen yang paling penting dalam sebuah pembangunan nasional adalah faktor dari manusia. Berbagai upaya untuk meningkatkan sumber daya manusia telah dilakukan oleh pemerintah melalui pelatihan peningkatan kualitas guru, penyempurnaan kurikulum, serta penyediaan sarana dan prasarana yang dapat menunjang mutu pendidikan. Hal tersebut dilaksanakan untuk mencapai tujuan pembelajaran di sekolah agar optimal.

Proses pembelajaran di sekolah dapat berjalan dengan optimal apabila penyelenggaraan pendidikan di sekolah melibatkan guru dan siswa, dalam bentuk interaksi belajar mengajar dengan menggunakan model pembelajaran. Dalam pelaksanaan belajar mengajar guru perlu menyiapkan rencana pembelajaran atau RPP secara sistematis dan berpedoman pada kurikulum yang diterapkan.

Pembelajaran siswa di sekolah diharapkan mengalami suatu perubahan, baik dalam bidang pengetahuan, sikap dan keterampilan. Perubahan tersebut dapat tercapai bila ditunjang dengan beberapa faktor. Salah satunya guru harus memiliki kemampuan mengajar, mendidik, dan melatih siswa kearah yang baik, sehingga siswa tidak hanya tahu, tetapi juga bisa dan 
dapat mempraktikkan ilmu yang didapat di sekolah. Guru juga harus kreatif agar dapat menyampaikan pembelajaran menjadi menarik dan disukai oleh siswa. Guru yang kreatif dalam perencanaan pembelajaran berdampak baik pada siswa. Siswa menjadi aktif dan kreatif dalam pembelajaran, sehingga siswa terlibat langsung dalam proses belajar mengajar. Keterlibatan siswa secara langsung, berpengaruh terhadap pemahaman siswa yang maksimal. Dan dengan menggunakan model pembelajaran diharapkan akan membuat siswa lebih semangat untuk mengikuti pemblajaran.

Salah satu Pendidikan yang paling dasar adalah di jenjang sekolah dasar (SD). Pendidikan sekolah dasar merupakan awal mengenal Pendidikan formal. Dengan kemajuan ilmu pengetahuan dan teknologi menuntut siswa sekolah dasar dalam bidang akademis, terutama dalam bidang 5 mata pelajaran yaitu PKn, Bahasa Indonesia, Matematika, IPA, IPS yang menuntut siswa untuk mempunyai fikiran yang demokratis, dan bertanggung jawab. Seperti yang sering di lihat, kebanyakan anak susah untuk menyayangi alam disekitarnya, oleh karena itu diperlukan Pendidikan yang berkaitan dengan alam yaitu mata pelajaran IImu Pengetahuan Alam. Pembelajaran IPA di sekolah dasar merupakan wahana untuk membekali siswa dengan pengetahuan, keterampilan, dan sikap yang diperlukan untuk melanjutkan pendidikan dan untuk menyesuaikan diri dengan perubahan-perubahan disekelilingnya.

IPA (sains) berupaya membangkitkan minat manusia agar mau meningkatkan kecerdasan dan pemahamannya tentang alam seisinya yang penuh dengan rahasia yang tak habis-habisnya. IPA di SD hendaknya juga membuka kesempatan memupuk rasa ingin tau anak didik secara alamiah. Hal ini akan membantu mereka mengembangkan cara berfikir ilmiah. Fokus program pengajaran IPA di SD hendaknya ditunjukkan untuk memupuk minat dan pengembangan anak didik terhadap dunia mereka di mana mereka hidup.

Usman, 2010:1 menyatakan bahwa "IPA/sains sebagai suatu deretan konsep serta skema konseptual yang berhubungan satu sama lain, dan yang tumbuh sebagai hasil eksmperimentasi dan observasi terhadap gejala atau fakta (orde observasi), dan didasarkan pada konsep-konsep manusia mengenai alam'.

Pentingnya pembelajaran IPA, mewajibkan guru untuk dapat menciptakan suasana serta lingkungan belajar kondusif. Lingkungan belajar yang kondusif memungkinkan siswa memperoleh pengalaman belajar melalui interaksi positif, baik interaksi antara siswa dengan guru maupun interaksi antara siswa dengan siswa demi tercapainya tujuan pembelajaran IPA. Ketercapaian tujuan pembelajaran dalam pembelajaran IPA pada siswa dapat diukur dengan melihat hasil belajar siswa.

Namun upaya yang dilakukan untuk meningkatkan kualitas peserta didik nampaknya belem optimal. Salah satunya yaitu dengan menggunakan model pembelajaran. Pemilihan model pembelajaran sangat mempengaruhi proses belajar siswa. Dengan penggunaan model pembelajaran yang tepat, maka dapat meningkatkan hasil dan partisipasi peserta didik dalam proses pembelajaran. Peserta didik akan lebih aktif dalam proses pembelajaran sehingga pembelajaran dapat berlangsung secara efektif dalam mencapai suatu kompetensi. Dengan tercapainya kompotensi, maka akan berakibat pada peningkatan prestasi belajar peserta didik pada proses pembelajaran. Namun kenyataan dilapangan berdasarkan hasil observasi nilai dan wawancara yang dilakukan di SD Gugus Sriwijaya, Pekutatan, Kabupaten Jembrana yang menerapkan dua kurikulum yaitu KTSP dan kurikulum 2013.

Berdasarkan data studi dokumentasi yang dilakukan pada tanggal 6 dan 7 Desember 2017 diperoleh hasil tes akhir semester 1 siswa kelas III SD di Gugus Sriwijaya Kecamatan Pekutatan tahun pelajaran 2017/2018, khususnya pada mata pelajaran IPA. Berdasarkan hasil observasi dapat dilihat bahwa dari 122 siswa kelas III di Gugus Sriwijaya Kecamatan Sriwijaya terdapat 92 siswa yang belum tuntas karena tidak sesuai dengan nilai KKM ulangan akhir semester (UAS) pada mata pelajaran IPA masih di bawah KKM. Adapun presentase ketuntasan yang belum mampu mencapai KKM sebesar 24,27\%. Yang membuktikan bahwa hasil belajar siswa pada mata pelajaran IPA SD di Gugus Sriwijaya Kecamatan Pekutatan masih rendah.

Berdasarkan hasil wawancara bersama guru kelas III pada masing-masing SD di Gugus Sriwijaya Kecamatan Pekutatan Kabupaten Jembrana, diketahui bahwa pengunaan metode 
ceramah disebabkan oleh jumlah siswa yang cukup banyak pada beberapa SD dan guru harus menyelesaikan materi sesuai dengan waktu yang telah ditentukan. Guru sudah pernah menerapkan pembelajaran inovatif pada beberapa materi dengan menggunakan sistem kelompok, namun saat pembelajaran berlangsung siswa sulit diatur, bercanda dalam kelompok, sehingga proses pembelajaran menjadi kurang efektif.

Pada Pelaksanaan observasi dan wawancara yang telah dilakukan dengan guru kelas III SD di Gugus Sriwijaya Kecamatan Pekutatan pada tanggal 9 Januari 2018, terdapat beberapa permasalahan yang menjadi faktor penyebab rendahnya hasil belajar IPA yang disampaikan oleh wali kelas III di gugus Sriwijaya Kecamatan Pekutatan. Pertama, adanya kecenderungan guru dalam memilih dan menggunakan metode ceramah, tanya jawab, dan pemberian tugas. Dengan kata lain bahwa pembelajaran lebih berpusat pada guru. Pembelajaran yang masih berpusat pada guru menyebabkan siswa belum mendapatkan kesempatan berpikir aktif untuk menemukan sendiri konsep yang dipelajari, siswa belum mendapatkan kesempatan optimal untuk melakukan interaksi berupa diskusi dengan siswa lain, serta siswa belum mendapatkan kesempatan untuk dapat mengutarakan pendapat atau hasil pemikiran secara optimal. Kedua, Siswa merasa cepat bosan di dalam menerima materi pelajaran karena dalam proses pembelajaran tidak menggunakan Model dan media pembelajaran. Ketiga, Di dalam melakukan diskusi siswa cenderung hanya memilih teman-teman terdekatnya saja tanpa memperhitungkan kemampuan akademiknya dalam memilih anggota kelompok sehingga kegiatan diskusi kurang maksimal. Keempat, Kurangnya media pembelajaran dalam proses pembelajaran, membuat siswa kurang termotivasi untuk belajar. Dari hasil wawancara dan observasi upaya yang dapat dilakukan oleh guru agar siswa aktif, termotivasi untuk mengikuti proses pembelajaran yaitu dengan memilih model Kooperatif Tipe TPS Berbatuan Media Visual.

Salah satu metode yang dapat digunakan yaitu metode pembelajaran kooperatif tipe Think Pair Share (TPS). Dalam metode kooperatif tipe TPS ini, pembelajaran dilakukan dengan terlebih dahulu memberikan masalah kepada siswa yang harus dipecahkan secara individual (Think) kemudian guru membagi siswa secara berpasangan dalam kelompok (Khaerunnisa, 2017).

Melalui model pembelajaran Kooperatif Tipe TPS Berbatuan Media Visual siswa akan lebih aktif mengikuti proses pembelajaran. Menurut Slavin (dalam Fathurrohman, 2015) pembelajaran kooperatif adalah proses pembelajaran siswa harus terlibat aktif dan menjadi pusat kegiatan pembelajaran dikelas, siswa berinteraksi secara aktif dan positif dalam kelompok, Model pembelajaran ini dikembangkan dari teori belajar konstruktivisme yang lahir dari gagasan Piaget dan Vigotsky. Dalam Model pembelajaran kooperatif ini, guru lebih berperan sebagai fasilitator yang berfungsi sebagai jembatan penghubung kearah pemahaman yang lebih tinggi, dengan catatan siswa sendiri. Guru tidak hanya memberikan pengetahuan pada siswa, tetapi juga harus membangun pengetahuan dalam pikirannya. Siswa mempunyai kesempatan untuk mendapatkan pengalaman langsung dalam menerapkan ide-ide mereka, ini merupakan kesempatan bagi siswa untuk menemukakan dan menerapkan ide-ide mereka sendiri. Strategi pembelajaran kooperatif merupakan serangkaian kegiatan pembelajaran yang dilakukan oleh siswa di dalam kelompok, untuk mencapai tujuan pembelajaran yang telah ditetapkan. Terdapat empat hal penting dalam strategi pembelajaran kooperatif, yakni: (1) adanya peserta didik dalam kelompok, (2) adanya aturan main(role) dalam kelompok, (3) adanya upaya belajar dalam kelompok, (4) adanya kompetensi yang harus dicapai oleh kelompok. Model pembelajaran kooperatif tipe TPS atau berpikir berpasangan berbagi adalah jenis pembelajaran kooperatif yang sengaja dirancang agar terjadi interaksi antar siswa. Dengan kata lain, model ini adalah suatu model pembelajaran yang mengemas pembelajaran berkelompok yang memberi siswa kesempatan lebih untuk berpikir dan merespon serta saling bantu satu sama lain.

Metode ini memberi kesempatan pada siswa untuk berfikir dan saling bantu satu sama lain. Dengan sendirinya ini juga mendorong tumbuhnya sikap kesetiakawanan dan keterbukaan diantara siswa. Pola interaksi yang bersifat terbuka dan langsung diantara anggota kelompok sangat penting bagi siswa untuk memperoleh keberhasilan belajarnya. Keadaan inilah yang 
memberikan peluang bahwa penggunaan pembelajaran kooperatif Think Pair Share (TPS) dapat meningkatkan hasil belajar siswa (Kormiana ,2017).

Kurniasih (2015:58) model pembelajaran kooperatif tipe TPS merupakan suatu cara yang efektif untuk membuat variasi suasana pola diskusi kelas yang membutuhkan pengaturan untuk mengendalikan kelas secara keseluruhan, dan prosedur yang digunakan dalam TPS dapat memberi siswa lebih banyak waktu berpikir, untuk merespon dan saling membantu. Model pembelajaran TPS menggunakan metode diskusi berpasangan yang dilanjutkan dengan diskusi pleno. Dengan model pembelajaran ini siswa dilatih bagaimana mengutarakan pendapat dan siswa juga belajar menghargai pendapat orang lain dengan tetap mengacu pada materi atau tujuan pembelajaran. Selain menggunakan model pembelajaran yang membuat siswa semangat belajar, guru juga perlu menggunakan media pembelajaran sebagai alat bantu dalam proses pembelajaran. Pelajaran IPA di sekolah dasar alangkah lebih baik jika dipadukan dengan media pembelajaran, karena banyak materi pembelajaran IPA yang sulit dijelaskan dengan buku saja. Penggunaan media dalam pelajaran IPA di sekolah dasar sangatlah bermanfaat, karena dapat membangkitkan rangsangan kegiatan belajar IPA. Secara tidak langsung siswa termotivasi untuk belajar dan pembelajaran akan menjadi lebih menarik. Salah satu media pembelajaran yang cocok untuk anak usia sekolah dasar adalah media visual.

Hasil belajar merupakan sesuatu yang diperoleh siswa setelah mengikuti proses pembelajaran. Menurut Kunandar (2007) "hasil belajar adalah kemampuan siswa dalam memenuhi suatu tahapan pencapaian pengalaman belajar dalam satu kompetensi dasar". Menurut Abdurrahman (2003), "hasil belajar adalah kemampuan yang diperoleh anak setelah melalui kegiatan belajar" (Irma, 2016).

Menurut Sukmadinata (dalam Sukriswati, 2016) menyatakan bahwa hasil belajar merupakan realisasi atau pemekaran dari kecakapan-kecakapan potensi atau kapasitas yang dimiliki seseorang. Menurut Nana Sudjana (dalam Sukriswati, 2016) hasil belajar merupakan kemampuan- kemampuan yang dimiliki setelah ia menempuh pengalaman belajarnya (proses belajar mengajar) (Ariyanto, 2016).

Pengertian media pembelajaran anatara lain disampaikan oleh beberapa pakar pendidikan. Mulyani Sumantri (2000: 125) menuliskan: menurut Bringgs (1970) ialah segala alat fisik yang dapat menyajikan pesan serta perangsang peserta didik untuk belajar, contoh buku, film, kaset. Aristo Rahardi (2003: 9) menuliskan menurut Asosiasi Teknologi Komunikasi Pendidikan (AECT), media pembelajaran adalah segala sesuatu yang digunakan orang untuk menyalurkan pesan. Sedangkan Noehi Nasution (2004: 7) menuliskan media pembelajaran menurut (1) Gagne, media pembelajaran sebagai komponen sumber belajar di lingkungan siswa yang dapat merangsang siswa untuk belajar, (2) Briggs, media pembelajaran adalah wahana fisik yang mengandung materi pelajaran dan (3) Wilbur Schramm, media pembelajaran adalah teknik pembawa informasi atau pesan pembelajaran. Yusuf Hadi Miarso: media pembelajaran adalah segala sesuatu yang dapat merangsang terjadi nya proses belajar mengajar. (Rohman, 2013: 156) (Adam, 2015).

Media visual adalah media yang melibatkan indera penglihatan. Media visual sebagai sumber belajar yang berisikan pesan atau materi pelajaran yang dibuat secara menarik dalam bentuk kombinasi gambar, teks, gerak dan animasi yang disesuaikan dengan kebutuhan dan usia peserta didik. Media visual digunakan agar dapat menarik peserta didik dalam belajar, sehingga pembelajaran akan menyenangkan dan tidak menjenuhkan. Hal ini sejalan dengan pendapat Yudhi (2013:81) yang menyebutkan bahwa "media visual media yang melibatkan indera penglihatan".

Media visual sangat cocok diterapkan bersamaan dengan model pembelajaran TPS dalam pembelajaran IPA yang membahas materi tentang segala hal yang terjadi di alam. Pembelajaran dengan pemilihan model pembelajaran yang dipadukan dengan media pembelajaran yang tepat oleh guru, dapat membantu siswa untuk belajar secara optimal. Oleh karena itu, melalui model pembelajaran TPS berbantuan media visual diharapkan dapat meningkatkan semangat, keaktifan siswa yang pada akhirnya akan berdampak pada hasil belajar siswa. Hal ini karena pada model TPS, siswa tidak hanya dituntut agar mampu bertanggung jawab terhadap diri sendiri, tetapi juga dituntut agar mampu bertanggung jawab 
terhadap pasangannya. Selain itu, diharapkan agar mata pelajaran IPA yang selama ini kurang mendapat perhatian secara optimal dari siswa karena dianggap membosankanakan digantikan menjadi pembelajaran IPA yang menyenangkan dan selalu dinanti-nantikan oleh siswa. Dengan demikian tujuan pembelajaran IPA akan tercapai secara optimal.

Berdasarkan uraian di atas, untuk mencapai hasil belajar siswa yang optimal, dilakukan penelitian yang berjudul "Pengaruh Model Pembelajaran Kooperatif Tipe Think Pair Share Berbantuan Media Visual Terhadap Hasil Belajar IPA Siswa Kelas III SD Gugus Sriwijaya Kecamatan Pekutatan, Kabupaten Jembrana Tahun Pelajaran 2017/2018".

Tujuan penelitian ini, yaitu untuk mengetahui perbedaan yang Signifikan terhadap hasil belajar IPA antara siswa kelas III yang dibelajarkan melalui Model Pembelajaran Kooperatif Tipe Think-Pair Share berbantuan media visual dan siswa kelas III yang dibelajarkan melalui pembelajaran konvensional pada siswa SD Gugus Sriwijaya, Kecamatan Pekutatan, Kabupaten Jembrana Tahun Pelajaran 2017/2018.

\section{Metode}

Jenis penelitian ini adalah penelitian eksperimen semu (quasi experiment). Penelitian ini menggunakan desain Nonequivalent Posttest-Only Control Group Design. Desain penelitian ini dipilih karena tidak mungkin mengubah kelas-kelas yang sudah ada, jadi tidak bisa mengubah struktur yang ada. Terdapat dua kelompok dalam penelitian ini yang dipilih secara acak. Kelompok pertama diberi perlakuan (X) menggunakan model pembelajaran Think Pair Share (TPS) dan kelompok yang lain tidak diberikan perlakuan (-) menggunakan model pembelajaran Think Pair Share (TPS) sehingga dibelajarkan dengan pembelajaran konvensional. Kelompok yang diberikan perlakuan disebut kelompok eksperimen dan kelompok yang tidak diberikan perlakuan disebut kelompok kontrol. Populasi dalam penelitian ini adalah seluruh siswa kelas III di SD Gugus Sriwijaya Kecamatan Pekutatan tahun pelajaran 2017/2018 yang berjumlah 122 orang siswa. Sampel yang digunakan telah diuji kesetaraannya. Sampel penelitian adalah siswa kelas III di SD Negeri 1 Asahduren dan SD Negeri 2 Asahduren yang dipilih dengan teknik random sampling.

Dalam penelitian ini terdapat dua variabel yakni variabel bebas dan variabel terikat. Model pembelajaran Think Pair Share (TPS) dan pembelajaran konvensional sebagai variabel bebas dan hasil belajar IPA sebagai variabel terikat. Metode pengumpulan data yang digunakan pada penelitian ini adalah metode tes dengan memberikan tes pilihan ganda setelah diberlakukannya model pembelajaran Think Pair Share (TPS) dan pembelajaran konvensional. Sebelum digunakan dalam posttest, tes atau alat ukur yang digunakan diuji cobakan. Uji coba tes hasil belajar IPA meliputi; validitas isi, validitas butir, reliabilitas tes, daya beda tes dan tingkat kesukaran tes. Pada penelitian ini, digunakan dua metode analisis yaitu metode analisis statistik deskriptif dan statistik inferensial. Metode analisis data yang digunakan untuk menguji hipotesis dalam penelitian ini adalah Uji-t penelitian eksperimen Sampel Independent Polledd varian (tidak berkorelasi). Sebelum dilakukan uji hipotesis dengan metode statistika tersebut, terlebih dahulu dilakukan uji prasyarat analisis yang meliputi uji normalitas sebaran data dengan menggunakan analisis Chi-Kuadrat, dan uji homogenitas varians dengan menggunakan uji F.

\section{Hasil Dan Pembahasan}

Data hasil penelitian yang dianalisis adalah data berbentuk skor. Data hasil belajar IPA siswa didapatkan dari posttest. Instrumen yang digunakan untuk posttest sudah valid secara kriteria yang ditetapkan berdasarkan hasil analisis uji coba instrumen penelitian. Jumlah soal posttest hasil belajar IPA adalah sebanyak 25 butir pilihan ganda. Selama kegiatan posttest, siswa di kelas eksperimen serta kelas kontrol hadir secara keseluruhan. Jumlah pertemuan pada masing-masing kelas eksperimen dan kelas kontrol adalah sebanyak 7 kali pertemuan.

Data yang diperoleh dalam penelitian adalah data tentang hasil belajar IPA pada kelompok siswa yang mengikuti pembelajaran dengan model Think Pair Share (TPS) dan 
kelompok siswa yang mengikuti pembelajaran konvensional. Rincian data tentang kedua pembelajaran tersebut dianalisis dengan statistik deskriptif yang dihitung secara manual. Statistik deskriptif digunakan untuk mengetahui tinggi rendahnya kualitas dua variabel yaitu model pembelajaran Think Pair Share (TPS) dan pembelajaran konvensional. Deskripsi data kelompok eksperimen dan kelompok kontrol secara umum disajikan pada tabel 1 sebagai berikut.

Tabel 1. Rekapitulasi Hasil Perhitungan Skor Hasil Belajar IPA Siswa

\begin{tabular}{ccc}
\hline \multirow{2}{*}{ Statistik Deskriptif } & \multicolumn{2}{c}{ Hasil Belajar IPA } \\
& Kelompok Eksperimen & Kelompok Kontrol \\
\hline Mean & 19,48 & 13,04 \\
Median & 19,94 & 12,05 \\
Modus & 21 & 11 \\
Varian & 8,40 & 8.19 \\
Standar Deviasi & 2,90 & 2,86 \\
Skor Maksimum & 24 & 19 \\
Skor Minimum & 13 & 8 \\
Rentangan & 12 & 12 \\
\hline
\end{tabular}

Hasil penghitungan analisis deskriptif menunjukkan bahwa rata-rata skor hasil belajar IPA yang diperoleh oleh kelompok siswa yang mengikuti pembelajaran dengan model Think Pair Share (TPS) Kelompok eksperimen adalah 19,48 dan rata-rata skor hasil belajar IPA yang diperoleh oleh kelompok siswa yang mengikuti pembelajaran dengan konvensional Kelompok kontrol adalah 13,04. Dengan demikian, hasil belajar IPA siswa yang mengikuti pembelajaran dengan model Think Pair Share (TPS) (kelompok eksperimen) lebih baik dibandingkan dengan siswa yang mengikuti pembelajaran konvensional (kelompok kontrol). Berdasarkan uraian deskripsi data hasil belajar IPA kelompok eksperimen dan kelompok kontrol dapat ditentukan tinggi rendahnya kualitas kedua variable tersebut. Untuk menentukan tinggi rendahnya kualitas variabel maka skor rata-rata (mean) tiap-tiap variabel dikonversikan dengan menggunakan kriteria rata-rata ideal (Mi) dan standar deviasi ideal (SDi). Sebelum dimasukkan ke dalam konversi skala penilaian kategori skala lima, terlebih dahulu di hitung rata-rata skor (mean) dan standar deviasi (SD). Adapun penentuan tinggi rendahnya hasil belajar IPA kelompok eksperimen dan kelompok kontrol dengan kualifikasi menggunakan pedoman konversi skala lima dapat disajikan pada Tabel 2 berikut:

Tabel 2. Hasil Skala Penilaian atau kategori pada skala lima

\begin{tabular}{cc}
\hline Rentang Skor & Kategori \\
\hline $22,50 \leq X \leq 30,00$ & Sangat tinggi \\
$17,50 \leq X<22,50$ & Tinggi \\
$12,50 \leq X<17,50$ & Sedang \\
$7,50 \leq X<12,50$ & Rendah \\
$0,00 \leq X<7,50$ & Sangat rendah \\
\hline
\end{tabular}

Nilai rata-rata hasil belajar IPA kelompok eksperimen dengan menerapkan model pembelajaran Think Pair Share (TPS) adalah 19,48. Berdasarkan Tabel 2 rata-rata (X) skor hasil belajar pada mata pelajaran IPA kelompok eksperimen terletak pada kategori sangat tinggi yaitu 19,48 yang berada pada rentangan $22,5 \square \mathrm{X} \square 30,00$ sedangkan, nilai rata-rata hasil belajar IPA kelompok kontrol dengan menerapkan pembelajaran konvensional adalah 13,04. Berdasarkan Tabel 2 rata-rata $(\mathrm{X})$ skor hasil belajar IPA kelompok kontrol terletak pada kategori sedang yaitu 13,04 yang berada pada rentangan 12,5 $\square$ X $\square$ 17,5. Berdasarkan 
analisis data yang dilakukan, dapat disajikan hasil uji normalitas sebaran data hasil belajar IPA kelompok eksperimen dan kelompok kontrol pada Tabel 3 berikut.

Tabel 3. Rangkuman Hasil Uji Normalitas Sebaran Data

\begin{tabular}{llccc}
\hline No & Kelompok Data Hasil Belajar IPA & $\chi^{2}{ }_{\text {hitung }}$ & $\chi^{2}$ tabel & Status \\
\hline 1 & Post-test Eksperimen & 2,911 & 7,815 & Normal \\
2 & Post-test Kontrol & 2,894 & 7,815 & Normal \\
\hline
\end{tabular}

Kriteria pengujian, jika $\chi^{2}{ }_{h i t}<\chi_{\text {tab }}^{2}$ dengan taraf signifikasi $5 \%$ (dk $=$ jumlah kelas dikurangi parameter, dikurangi 1), maka data berdistribusi normal. Sedangkan, jika $\chi_{h i t}^{2} \geq \chi_{t a b}^{2}$, maka sebaran data tidak berdistribusi normal. Berdasarkan hasil perhitungan degan menggunakan rumus chi-kuadrat, diperoleh $\chi^{2}$ hit hasil post-test kelompok eksperimen adalah 2,911 dan $\chi^{2}{ }_{t a b}$ dengan taraf signifikasi $5 \%$ dan $\mathrm{db}=3$ adalah 7,815 . Hal ini berarti, $\chi^{2}{ }_{h i t}$ hasil post-test kelompok eksperimen lebih kecil dari $\chi^{2}{ }_{t a b}\left(\chi_{h i t}^{2}<\chi^{2}{ }_{t a b}\right)$, sehingga data hasil post-test kelompok eksperimen berdistribusi normal. Sedangkan, $\chi^{2}$ hit hasil post-test kelompok kontrol adalah 2,894 dan $\chi^{2}{ }_{\text {tab }}$ dengan taraf signifikansi $5 \%$ dan $\mathrm{db}=3$ adalah 7,815. Hal ini berarti, $\chi^{2}{ }^{h i t}$ hasil post-test kelompok kontrol lebih kecil dari $\chi_{\text {tab }}^{2}$ $\left(\chi^{2}{ }_{h i t}<\chi_{t a b}^{2}\right)$, sehingga data hasil post-test kelompok kontrol berdistribusi normal.

Pada penelitian ini, uji homogenitas dilakukan terhadap varians antar kelompok eksperimen dan kelompok kontrol. Uji yang digunakan adalah uji-F dengan kriteria data homogen jika Fhitung < Ftabel. Rekapitulasi hasil uji homogenitas varians antar kelompok eksperimen dan kelompok kontrol disajikan pada Tabel 4 berikut:

Tabel 4. Hasil Uji Homogenitas Varians antar Kelompok Eksperimen dan Kontrol

\begin{tabular}{llcccc}
\hline \multicolumn{2}{c}{ Data } & $F_{\text {hitung }}$ & $F_{\text {tabel }}$ & Kesimpulan \\
\hline $\begin{array}{l}\text { Post-Test } \\
\text { Kelompok Kontrol }\end{array}$ & Eksperimen & dan & 1,05 & 1,99 & Homogen \\
\hline
\end{tabular}

Berdasarkan Tabel di atas, diketahui $F_{\text {hit }}$ hasil kelompok eksperimen dan kontrol adalah 1,05 sedangkan $F_{\text {tab }}$ pada $\mathrm{db}_{\text {pembilang }}=28, \mathrm{db}_{\text {penyebut }}=26$, dan taraf signifikansi $5 \%$ adalah 1,99. Hal ini berarti, varians data hasil belajar IPA kelompok eksperimen dan kontrol adalah homogenUntuk pembuktian hipotesis yang diajukan dilakukan pengujian dengan menggunakan uji-t sampel independent (tidak berkorelasi) dengan rumus polled varians. Adapun hasil analisis uji-t disajikan pada Tabel 5 berikut:

Tabel 5. Hasil Uji-T

\begin{tabular}{lcccccc}
\hline Kelompok & $\mathrm{N}$ & $\mathrm{Db}$ & Mean & $\mathrm{s}^{2}$ & $\mathrm{t}_{\text {hit }}$ & $\mathrm{t}_{\text {tab }}$ \\
Eksperimen & 29 & \multirow{5}{*}{54} & 19,48 & 8,40 & 8,473 & 2,021 \\
Kontrol & 27 & & 13,04 & 8,19 & & \\
\hline
\end{tabular}

Berdasarkan Tabel analisis di atas, dapat diketahui $t_{\text {hit }}=8,473$ dan $t_{\text {tab }}=2,021$ untuk $\mathrm{db}=$ 54 pada taraf signifikansi $5 \%$. Berdasarkan kriteria pengujian, karena $t_{\text {hit }}>t_{\text {tab }}$ maka $H_{0}$ ditolak 
dan $\mathrm{H}_{1}$ diterima. Artinya, terdapat terdapat pengaruh yang signifikan model pembelajaran Kooperatif Tipe Think Pair Share berbantuan media visual pada siswa kelas III SD Gugus Sriwijaya Kecamatan Pekutatan.

Hasil analisis data menunjukkan bahwa terdapat perbedaan hasil belajar antara kelompok siswa yang mengikuti model pembelajaran Kooperatif Tipe Think Pair Share berbantuan media visual dengan siswa yang mengikuti model pembelajaran konvensional. Tinjauan ini didasarkan pada hasil uji-t dan rata-rata skor hasil belajar siswa. Analisis data menggunakan uji-t, diketahui $t_{\text {hit }}=8,473$ dan $t_{\text {tab }}$ pada taraf signifikansi $5 \%=2,021$. Hasil perhitungan tersebut menunjukkan bahwa $t_{\text {hit }}>t_{\text {tab }}$, sehingga hasil penelitian adalah signifikan. Hal ini berarti, terdapat perbedaan hasil belajar antara kelompok siswa yang mengikuti model pembelajaran Kooperatif Tipe Think Pair Share dengan siswa yang mengikuti model pembelajaran konvensional.

Model pembelajaran kooperatif merupakan model yang lebih menekankan pada kepentingan bersama sehingga siswa yang pintar bisa berbagi dengan siswa yang tergolong biasa saja, demikian pula sebaliknya. Oleh karena itu, model pembelajaran kooperatif sangat cocok diterapkan dalam proses pembelajaran karena dapat membangkitkan rasa kekeluargaan dan rasa saling memiliki pada diri siswa.Salah satu model pembelajaran kooperatif yang cocok digunakan di jenjang sekolah dasar adalah model pembelajaran kooperatif tipe TPS.

Model pembelajaran TPS adalah salah satu model pembelajaran kooperatif yang dirancang untuk mengajarkan cara berinteraksi kepada siswa. Model pembelajaran ini adalah suatu model yang mengedepankan siswa untuk berperan aktif bersama dengan teman kelompoknya dengan cara berdiskusi untuk memecahkan suatu permasalahan yang diberikan oleh guru.

Adapun kelebihan dari model TPS yaitu: a) Model ini dengan sendirinya memberikan kesempatan yang banyak kepada siswa untuk berfikir, menjawab, dan saling membantu satu sama lain, b) Dapat meningkatkan partisipasi siswa dalam proses pembelajaran, c) Lebih banyak kesempatan untuk konstribusi masing-masing anggota kelompok, d) Adanya kemudahan interaksi sesama siswa, e) Lebih mudah dan cepat membentuk kelompoknya, f) Antara sesama siswa dapat keterampilan berfikir, menjawab dan berkomunikasi antara satu dengan yang lain, serta bekerja saling membantu dalam kelompok kecil, g) Dapat memperbaiki rasa percaya diri dan semua siswa diberi kesempatan untuk berpatisipasi di dalam kelas, $h$ ) Siswa dapat mengembangkan keterampilan berpikir dan menjawab dalam komunikasi satu dengan yang lain, serta bekerja saling membantu dalam kelompok kecil, i) Pemecahan masalah dapat dilakukan secara langsung, dan siswa dapat memahami sustau materi secara berkelompok dan saling membantu mempresentasikan di depan kelas sebagai salah satu langkah evaluasi terhadp kegiatan prmbelajaran yang telah dilakukan, j) Siswa akan terlatih untuk membuat konsep pemecahan masalah, k) Keaktifan siswa meningkat, karena kelompok yang dibentuk tidak gemuk, dan masing-masing siswa dapat leluasa mengeluarkan pendapat mereka, I) Siswa memperoleh kesempatan untuk mempresentasikan hasil diskusinya dengan seluruh siswa sehingga ide yang mereka dapatkan menyebar pada setiap anak, $\mathrm{m}$ ) Pelaksanaan model pembelajaran ini menuntut siswa menggunakan waktunya untuk mengerjakan tugas-tugas atau permasalahan yang diberikan oleh guru di awal pertemuan sehingga diharapkan siswa mampu memahami agar siswa dapat selalu berusaha hadir pada setiap pertemuan, n) Tugas yang berikan oleh guru pada setiap pertemuan selain untuk melibatkan siswa secara aktif dalam proses pembelajaran juga dimaksudkan agar siswa dapat selalu berushaa hadir pada setiap pertemuan, o) Hasil belajar lebih mendalam, karena model TPS siswa dapat diidentifikasi secara bertahap materi yang diberikan, sehingga pada akhir pembelajaran hasil yang diperoleh siswa dapat lebih optimal, dan p) Meningkatkan sistem kerja sama dalam tim, sehingga siswa dituntut untuk dapat belajar berempati menerima pendapat orang lain atau mengakui secara positif jika pendapatnya tidak diterima.

Hal ini berbeda dengan pembelajaran konvensional pada kelas kontrol. Pembelajaran konvensional mencirikan pembelajaran yang berpusat pada guru. Secara teoritis, pembelajaran yang menggunakan model konvensional adalah pembelajaran tradisional atau disebut juga dengan metode ceramah, karena sejak dulu metode ini telah dipergunakan sebagai alat 
komunikasi lisan antara guru dengan anak didik dalam proses belajar dan mengajar. Dalam hal ini, terlihat bahwa pembelajaran kurang maksimal dalam meningkatkan hasil belajar siswa.

Dengan demikian hasil penelitian ini membuktikan bahwa model pembelajaran model pembelajaran kooperatif tipe TPS memberikan pengaruh terhadap hasil belajar siswa. Tentu saja dalam hal ini hasil belajar siswa meningkat. Hal ini dapat dilihat dari pembelajaran lebih banyak menekankan siswa aktif di dalam kelompoknya sedangkan guru hanya bertugas sebagai fasilitator dan motivator dalam pembelajaran.

Hambatan yang ditemukan ketika dilakukan penelitian pada kelas eksperimen tidak terlalu berarti. Hanya ada beberapa hambatan kecil seperti masih terdapat beberapa siswa yang suka bercanda dan kurang fokus dalam mengikuti proses pembelajaran tetapi hal tersebut sudah dapat ditanggulangi oleh guru dengan memberikan perhatian lebih kepada siswa yang bersangkutan. Sementara hambatan di kelas kontrol lebih banyak ditemukan. Hambatan-hambatan tersebut adalah banyak ditemukan siswa yang kurang memperhatikan guru saat menjelaskan materi seperti siswa bermain-main di kelas. Selain itu terdapat pula beberapa siswa yang bercanda pada saat proses pembelajaran berlangsung.

\section{Simpulan dan Saran}

Berdasarkan Berdasarkan hasil penelitian dan pembahasan di atas, dapat disimpulkan bahwa terdapat perbedaan yang signifikan hasil belajar IPA antara siswa yang mengikuti pembelajaran dengan model pembelajaran kooperatif Tipe TPS berbantuan media visual dan kelompok siswa yang mengikuti pembelajaran Konvensional pada kelas III SD Gugus Sriwijaya Kecamatan Pekutatan di Kabupaten Jembrana. Hal ini dapat dilihat dari nilai rata - rata hasil belajar IPA kelompok eksperimen lebih dari rata -rata nilai hasil belajar IPA pada kelompok kontrol ( $\bar{X}=19,48>\bar{X}=13,04$ ). Adanya perbedaan yang signifikan menunjukkan bahwa model pembelajaran kooperatif tipe think pair share (TPS) berbantuan media visual berpengaruh positif terhadap hasil belajar IPA siswa.

Saran yang dapat disampaikan berdasarkan penelitian yang telah dilakukan adalah sebagai berikut.

1. Kepala Sekolah

Penelitian ini menunjukkan bahwa hasil belajar pada mata pelajaran IPA yang belajar dengan model pembelajaran Think Pair Share berbantuan media visual lebih tinggi daripada siswa yang belajar dengan pembelajaran yang berpusat pada guru, oleh karena itu hekdaknya kepala Sekolah Dasar Gugus Sriwijaya Kecamatan Pekutatan untuk menerapkan model pembelajaran TPS dengan berbantuan media visual demi kualitas dan peningkatan hasil belajar siswa.

2. Kepada Guru

Hendaknya dalam pelaksanaan proses pembelajaran agar menerapkan model pembelajaran TPS berbantuan media visual atau model pembelajaran yang lain yang didukung dengan teknik belajar yang relevan, sehingga hasil belajar siswa semakin meningkat.

3. Kepada Peneliti Lain

Peneliti lain yang berminat untuk mengadakan penelitian lebih lanjut tentang model pembelajaran TPS berbantuan media visual dalam bidang IPA maupun ilmu lainnya agar memperhatikan kondisi siswa, waktu, dan kendala lainnya yang dialami dalam penelitian ini sebagai bahan pertimbangan perbaikan dan penyempurnaan penelitian yang akan dilakukan. 


\section{Daftar Rujukan}

Adam, Steffi .2015. Pemanfaatan Media Pembelajaran Berbasis Teknologi Informasi Bagi Siswa Kelas X Sma Ananda Batam . Journal, Volume 3 No 2, ISSN 2337-8794

Ariyanto, Metta. 2016. Peningkatan Hasil Belajar Ipa Materi Kenampakan Rupa Bumi Menggunakan Model Scramble . Jurnal Profesi Pendidikan Dasar, Vol. 3, No. 2, Desember 2016: 134 - 140

Departemen Pendidikan Nasional. 2003. Undang-Undang Republik Indonesia Nomor 20 Tentang Sistem Pendidikan Nasional.

Fathurrohman, Muhammad. 2015. Model-Model Pembelajaran Inovatif. Jogjakarta: AR-Ruzz Media.

Irma, Ayuwanti. Meningkatkan Aktivitas Dan Hasil Belajar Matematika Menggunakan Model Pembelajaran Kooperatif Tipe Group Investigation Di Smk Tuma'ninah Yasin Metro . Jurnal SAP Vol. 1 No. 2 Desember 2016 ISSN: 2527-967X

Kurniasih, Imas dan Berlin. Cetakan Pertama 2015. Ragam Pengembangan Model Pembelajaran: Kata Pena.

Khaerunnisa, Andi. 2017. Penerapan Metode Pembelajaran Kooperatif Tipe Think-Pair-Share Untuk Meningkatkan Hasil Belajar Siswa Kelas XI MIA.2 SMA Negeri 3 Model Takalar (Studi pada Materi Pokok Larutan Asam-Basa) . Jurnal Chemica Vo/. 18 Nomor 2 Desember 2017, 71 - 79

Kormiana, Ms .2017. Metode Think Pair Share (Tps) Untuk Meningkatkan Hasil Belajar Bahasa Inggris Siswa Sekolah Menengah Pertama . Jurnal IImu Pendidikan Sosial, sains, dan Humaniora Vol. 3 No. 1, Maret 2017

Munadi, Yudhi. Cetakan pertama 2013. Media Pembelajaran. Jakarta: Referensi (GP press Group).

Munirah. 2015 . Sistem Pendidikan Di Indonesia: Antara Keinginan Dan Realita . Jurnal Auladuna, Vol. 2 No. 2 Desember 2015: 233-245

Nurkholis. 2013. Pendidikan Dalam Upaya Memajukan Teknologi . Jurnal Kependidikan, Vol. 1 No. 1 Nopember 2013

Dantes, Nyoman. 2012. Metode Penelitian. Yogyakarta: C.V Andi Offset.

Koyan, I Wayan. 2012. Statistik Pendidikan Teknik Analisis Data Kuantitatif. Singaraja: Universitas Pendidikan Ganesha Press.

Sutrisno. 2016. Berbagai Pendekatan Dalam Pendidikan Nilai Dan Pendidikan Kewarganegaraan . Jurnal Dimensi Pendidikan dan Pembelajaran Vol.5 Januari 2016 